\author{
Mojca Smolej \\ Filozofska fakulteta Univerze v Ljubljani
}

\title{
Particle Clauses
}

The role of modification is often fulfilled by particle clauses, which enter into coordinate or subordinate relations with the preceding or following clause structures only at the formal, syntactic level, leaving the semantic level relation unfulfilled. An indispensable prerequisite for obtaining a grasp of the syntactic and semantic roles of particle clauses is to approach them from the construction perspective, as the construction method involves in its analysis both meaning and form, that is, structure.

Vlogo modifikacije nemalokrat opravljajo členkovni stavki, ki vstopajo v priredna ali podredna razmerja s pred ali za njimi stoječimi stavčnimi strukturami le na formalno skladenjski ravni, na pomenski ravni ostaja to razmerje (smiselno) neizpolnjeno. K razumevanju skladenjske in pomenske vloge členkovnih stavkov je nujno pristopiti s konstrukcijskega zornega kota. Konstrukcijska metoda namreč v svojo analizo hkratno vključuje tako pomen kot obliko oz. strukturo.

\section{Modification}

The definition of modifying action can be rather broad and elusive. In Slovenska slovnica (2000: pp. 492-533), for example, it is presented primarily through a description of various elements which have the role of modification. Since modification itself is not considered an obligatory constituent of the propositional action, the words serving as modifiers are not considered part of the proposition, either.

As modifiers are considered in Slovenska slovnica to subsume particles as well, the paper will begin by focusing on the terms 'modification' and 'modifier'. Their interpretation is based on the theory expounded in Slovenska slovnica (Toporišič 2000: 429-533).

Slovenian linguistics (Toporišič 2000: 492) associates the term 'modification' with the concept of verbalisation or proposition formation. The proposition may be modified in a number of ways: with regard to quantification, negation, the participants in the communication, emotional colouring, intensification, epistemic modality, and others. The devices which affect or produce modification are diverse, ranging from grammatical to lexical items. The latter are often represented by particles. As modifiers (that is, as devices which affect the formation of the proposition but are not part of it), particles occur most prominently at the levels of negation and of communicative role assignment (the syntactic mood) (Toporišič 2000: 497, 513-533). 
The modifying action is accordingly taken in the present paper to represent a constituent and fundamental part of the propositional action. The language devices fulfilling the role of modifiers are not part of the proposition, for they affect merely the process in which the proposition assumes a syntactic form (Toporišič 2000: 491).

The modifying action shall be taken to represent a fundamental starting-point for the analysis of particle clauses. It shall be demonstrated that the modifying role is fulfilled by, among others, clause structures (particle clauses) which are equal to particles precisely because of their basic role at the syntactic and semantic levels. As noted already in Slovenska slovnica, modifiers are not merely grammatical or lexical devices (Toporišič 2000: 513). The subsequent discussion shall focus on analysing the clause structures (that is, particle clauses) which resemble particles in reinforcing epistemic modality or expressing intensification, disagreement, rebuke, and other meanings.

\subsection{Particle clauses and the construction method}

Particle clauses are language devices which fulfil the same role as particles, the only difference being that they take the form of clauses. The role of particles and especially of particle clauses (clauses which are close or equal to particles because of their modifying role) can be presented comprehensively, with regard to both meaning and form/structure, with reference to construction grammar. The construction method or construction grammar is defined and promoted in W. Croft's work Radical Construction Grammar (2009). According to Croft, constructions are the basic, fundamental units of any syntactic examination, encompassing both form/structure and meaning (2009: 14-62). In the analysis of any language element at any language level, the construction approach always includes both meaning and form/structure. The startingpoint of the analysis is the function fulfilled by a given language element, such as a word, word phrase, clause, etc.

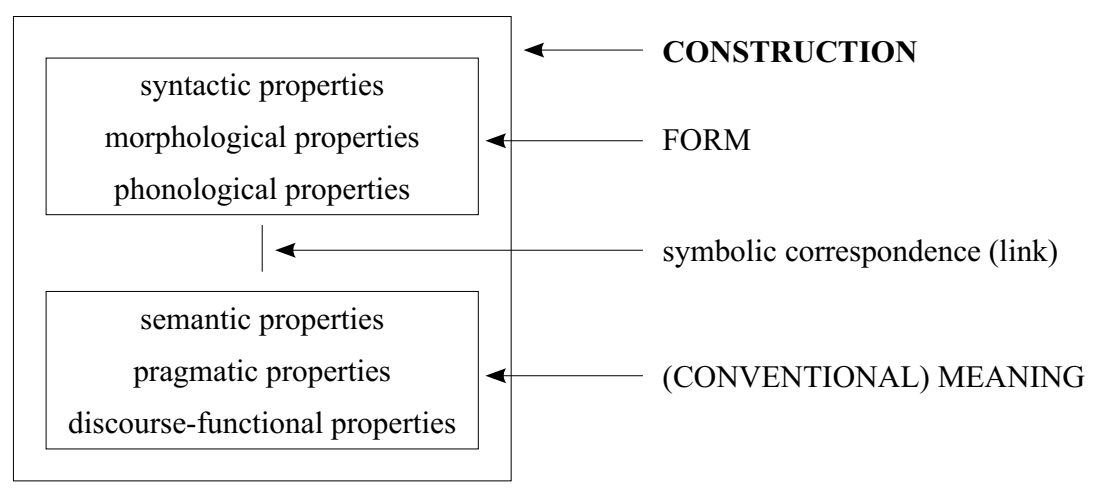

Table 1: The structure of a construction (Croft 2009: 18) 
For example, in order to analyse the role played by the word $d a$ in the sentence

"Da smo si na jasnem: tega ne trpim več!" (Let's get one thing straight: I won't put up with this anymore!) we shall start out from the function - that is, the modifying role - fulfilled by the clause of which $d a$ forms a part (Da smo si na jasnem // Word-for-word translation: So-that we-are for-ourselves in the clear // Sense-for-sense translation: Let's get one thing straight). Since it is the function that is our starting-point, the basic unit of analysis is the entire construction rather than a single language element, such as the lexeme $d a$. In other words, the modifying role of reinforcing the assertion and expressing emotionality is not fulfilled by the lexeme $d a$ on its own but by the entire clause. Therefore the word $d a$ is identified as a conjunction which plays the role of a particle - that is, a modifier together with other lexical and grammatical devices. Under certain circumstances, grammatical and lexical, the conjunction $d a$ undergoes a (tentative) conversion and serves as a particle; it does so, however, in the context of the whole structure rather than on its own.

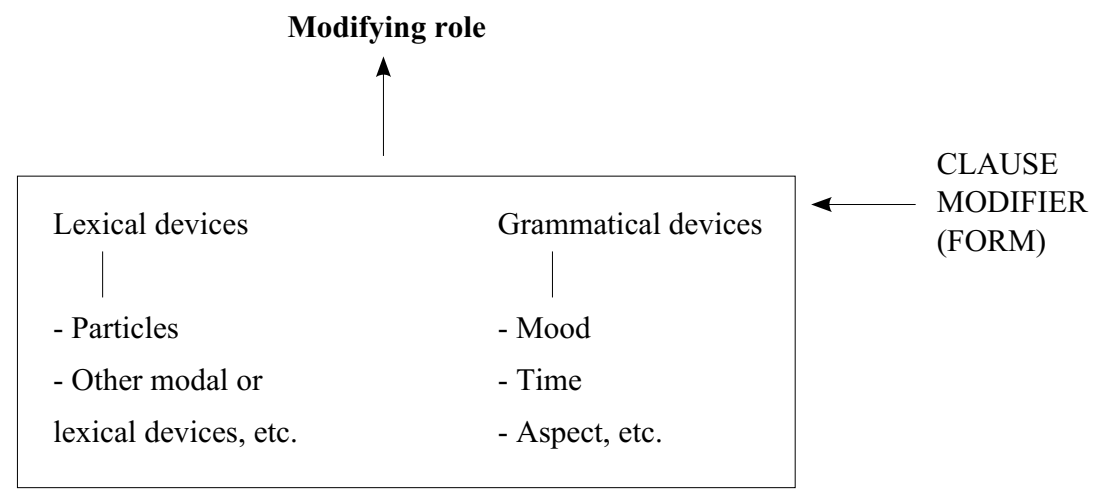

Table 2: Lexical and grammatical devices together fulfilling the role of the clause modifier

A precise identification of any function (not just modification) requires familiarity not only with the language devices which form the structure, but also with the word order syntax, the possibility of semantic transposition, the role of the context, the pragmatic role, etc.

\footnotetext{
${ }^{1}$ Source: www.sskj2.si/iskanje?Mode=Headword\&Query=da\#.
} 


\subsection{Particles as modifiers, the Slovene Grammar of 2000, $\mathrm{SSKJ}^{2}$ and the Dictio- nary of Particles}

The first treatment of particles as an independent word class in Slovene linguistics is found in a 1974 treatise by Jože Toporišič, "Kratko oblikoslovje slovenskega jezika".

The criterion for excluding certain words and word phrases from the group of adverbs is their inability to form the object of a question. Toporišič's paper divides particles into 13 groups, such as particles expressing emphasis, exception, judgment, reservations, etc. As suggested by the group names, this division is based on the type of semantic modification caused by a given particle in the sentence. Since this conception and division of particles, which are preserved with minor revisions even in the 2000 (most recent) edition of Slovenska slovnica (Toporišič 2000: 445-449), do not fully focus yet on the syntactic aspect of particle treatment, they provide no overview of other language devices or structures (such as particle clauses) whose modifying role resembles that of particles.

SSKJ (1991-1993) does not consider particles as a separate word class, being based on the Slovenska slovnica of 1956. Thus all words now classified as particles are defined as adverbs.

SSKJ $^{2}$ (2014), by contrast, does list the particle as a word class. Unfortunately, the dictionary is not fully consistent in its use of word-class qualifiers. The words $d a$ (so-that) and če (if), for example, have different definitions despite similar modifying roles: the word $d a$ is classified as a particle or a conjunction in particle use, ${ }^{3}$ while če is classified only as a conjunction, that is, without reference to its particle use.

Examples of the words $d a$ and če: ${ }^{4}$

\begin{tabular}{|l|l|l|}
\hline Example & Word-for-word translation & Sense-for-sense translation \\
\hline $\begin{array}{l}\text { 1. Ne maram zanj, da boš } \\
\text { vedel. }\end{array}$ & $\begin{array}{l}\text { Not I-care for-him, so-that } \\
\text { you-will know. }\end{array}$ & $\begin{array}{l}\text { I don't care for him, just so } \\
\text { you know. }\end{array}$ \\
\hline 2. Da mi pri priči izgineš! & $\begin{array}{l}\text { So-that for-me at once you- } \\
\text { disappear! }\end{array}$ & Will you get out of here! \\
\hline
\end{tabular}

${ }^{2}$ SSKJ: Slovar slovenskega knjižnega jezika.

${ }^{3}$ It would be worthwhile to elaborate on the difference between the qualifiers particle and in particle use. While $\mathrm{SSKJ}^{2}$ does explain the example of a qualifier in adjectival use (SSKJ ${ }^{2}$, I: p. 35), the explanation remains unclear because it states that the qualifier indicates a noun or adverb in attributive role. Now while the label of "adjectival use" suggests a definition in terms of word classes, the label of "attributive use" applies to the syntactic/functional role, and the two labels do not fully correspond to each other. The more accurate and (presumably) the more correct of the two would be the label in attributive use.

${ }^{4}$ The examples are taken from: www.sskj2.si/iskanje?Mode=Headword\&Query=da\#; www.sskj2.si/iskanje?Mode $=$ Headword\&Query $=\% \mathrm{C} 4 \% 8$ De. 


\begin{tabular}{|l|l|l|}
\hline $\begin{array}{l}\text { 3. Pa če ti rečem, da ga ni } \\
\text { doma! }\end{array}$ & $\begin{array}{l}\text { But if to-you I-say that he is- } \\
\text { not at-home! }\end{array}$ & $\begin{array}{l}\text { But if I'm telling you he's not } \\
\text { at home! }\end{array}$ \\
\hline 4. Če ti nisi prismojen! & If you are-not silly! & If you aren't a nutcase! \\
\hline 5. Oh, če bi nam že dali mir! & $\begin{array}{l}\text { Oh, if they-would to-us already } \\
\text { give peace! }\end{array}$ & $\begin{array}{l}\text { Oh, if they'd just leave us } \\
\text { alone! }\end{array}$ \\
\hline
\end{tabular}

The above examples display quite similar roles as they express similar modification. Nevertheless, the word $d a$ is defined as a particle or a conjunction in particle role used to express emphasis, that is, a wish or command, while the word če is characterised merely as an intensifying conjunction used to express an additional assertion, or as a conjunction expressing a wish or downtoned command. But despite the discrepancy in their word-class labels and consequently in the functions attributed to them, the very fact that they are defined in terms of their word class suggests a different, more appropriate conception of word classes, one which points to the construction approach. The construction approach (the focus of our last section) approaches the role of words - and thus indirectly of word classes - in an allencompassing functional and semantic framework, which requires that the identification of the role of a given word should consider also the other lexical and grammatical devices participating in the structure/construction. In the examples "Če ti nisi prismojen!", "Da mi pri priči izgineš!" and "Če ti rečem, da ga ni doma!", the lexemes če and $d a$ are not the only bearers of the modification values (despite the ostensible claim of the dictionary definition): they can only play the modifying role of expressing commands, etc in collaboration with other lexical and grammatical devices.

On the one hand, the $\mathrm{SSKJ}^{2}$ label of a conjunction in particle role or simply particle hints at a clearer, multifunctional, construction approach, according to which a given lexeme may fulfil various syntactic roles but still belong to a single word class. On the other hand, $\mathrm{SSKJ}^{2}$ keeps its distance from the construction approach in continuing to view the syntactic and semantic roles of the lexeme in isolation, without considering all lexical and grammatical devices participating in the fulfilment of syntactic and other roles.

The treatment of particles in Andreja Žele's Slovar členkov (2014) broadly follows the line of Slovenska slovnica 2000. Lexemes are defined in terms of word classes, depending on their syntactic role. The lexeme $d a$ (2014: 23), for example, is assigned to the word class of particles when it does not express a syntactic relation but has the modifying role of expressing emotionality or command. Etymologically it is explained as conversion from the conjunction $d a$. Finally, the functional and semantic explanation of each dictionary entry is accompanied with a clausal paraphrase: "Da mi pri priči izgineš!" is thus paraphrased as "Izgini!" (“Disappear!"). 
The account outlined above is significant for our discussion of particles and particle clauses. The clausal paraphrases ${ }^{5}$ provided in it demonstrate that particles should be analysed from the construction perspective. In other words, the particle does not express modification values on its own but only in collaboration with the other grammatical and lexical devices making up the propositional action. It is thus important to emphasise that the clausal paraphrase does not correspond to the particle itself but to the entire clause containing the particle. The etymological explanation, too, is significant as it clearly indicates that the lexeme $d a$ (2014: 23 ), for example, is primarily a conjunction $^{6}$ which may lose its original functions and acquire others under certain conditions. For this reason the $\mathrm{SSKJ}^{2}$ label of a conjunction in particle role is more telling and appropriate. In any event it would be a mistake to interpret the clausal paraphrase as referring to the conjunction alone - to the lexeme $d a$ or če. In fact, it paraphrases the modification formed by all lexical and grammatical devices in the clause, rather than by the $d a$ or če lexemes alone.

\section{Pseudo-hypotaxis}

A more accurate perception of particle clauses calls for at least a brief preliminary survey of two concepts: pseudo-hypotaxis and pseudo-parataxis.

Particle clauses (they might also be dubbed expressive clause structures) often enter into coordinate or subordinate relations with the preceding or following clause structures only at the formal, syntactic level, leaving the semantic level relation unrealised or void. Another possibility is a discrepancy between the semantic/deep level and the structural/surface level. ${ }^{7}$ Example of a pseudo-hypotactic clause:

6. Slovenija je bila leta 1988 dežela, v kateri se je končno ustavil vlak zgodovine (če kdaj, potem prav leta 1988 ni bilo razloga za beg iz Slovenije) /.../. Word-for-word translation: /.../ if ever, then just in-the-year 1988 not was-there reason for flight from Slovenia // Sense-for-sense translation: /.../ of all the years, 1988 was the least likely to drive anyone from Slovenia.

We shall focus on the relation between the two underlined clauses, "če kdaj" and "potem /.../ ni bilo razloga za beg /.../”. The pair displays no conditional or temporal, adversative or concessive relation. A semantic interpretation establishes that the role of the če $k d a j$ clause is close to that of a particle: the modifying role

${ }^{5}$ The first Slovene linguist to have addressed in more detail the particle role of compressing or replacing whole clauses was Jože Toporišič in his "Esej o slovenskih besednih vrstah" (1974/75). Here particles are presented as compressed clauses.

${ }^{6}$ The phenomenon of conversion.

${ }^{7}$ Especially at the school education level this causes many problems in the analysis of sentence elements, which is why particle clauses should urgently be viewed at a structural and syntactic level as well. 
of expressing reinforcement, that is, the reinforcement of certainty (epistemic modality) in the clause to which it refers (če $k d a j \rightarrow$ zagotovo: if ever $\rightarrow$ certainly). The če $k d a j$ clause is an expressive, pseudo-hypotactic clause structure which enters into a subordinate relation with the following clause only at a formal level. At the semantic level, this relation is void, for če $k d a j$ (merely) serves as a modifying device - a particle clause. Pseudo-hypotaxis is thus understood as a syntactic phenomenon which produces a diathesis, that is, incongruity between the structural and semantic levels. At the surface (structural) level, a pair of clauses may establish a subordinate or coordinate relation not supported by the deep (semantic) level. To give an example: two clauses may express subordination at the structural level, but the semantic level reveals that their relation is in fact a coordinate one, with the subordinate structure simply reinforcing the epistemic modality of the main clause.

\section{Examples and analysis of particle clauses}

Particle clauses are clauses which fulfil the role of modification and are close or equal to particles. They enter into coordinate or subordinate syntactic relations with the preceding or following clause structures, but these relations are limited to the formal, syntactic level, while the semantic level remains unrealised.

We shall continue by listing some common examples of particle clauses. They shall be analysed with the construction method, which involves considering both their meaning and form/structure.

\begin{tabular}{|c|c|c|}
\hline Example & Word-for-word translation & Sense-for-sense translation \\
\hline $\begin{array}{l}\text { 7. Če kaj vem, bo kmalu } \\
\text { svatba.* }\end{array}$ & $\begin{array}{l}\text { If anything I-know, there- } \\
\text { will-be soon a wedding. }\end{array}$ & $\begin{array}{l}\text { If I know anything, we'll } \\
\text { soon have a wedding. }\end{array}$ \\
\hline $\begin{array}{l}\text { 8. Če se na glavo postavišs, ne } \\
\text { dam.** }\end{array}$ & $\begin{array}{l}\text { If yourself on the head you- } \\
\text { stand, not I-give. }\end{array}$ & $\begin{array}{l}\text { I won't give it to you even if } \\
\text { you stand on your head. }\end{array}$ \\
\hline $\begin{array}{l}\text { 9. Če ti rečem, da je zanesljiv } \\
\text { mojster, no.*** }\end{array}$ & $\begin{array}{l}\text { If to-you I-say that he-is a } \\
\text { reliable craftsman, come-on. }\end{array}$ & $\begin{array}{l}\text { But I'm telling you he's a } \\
\text { reliable worker. }\end{array}$ \\
\hline
\end{tabular}

* Source: www.sskj2.si/iskanje?Mode=Headword\&Query=\%C4\%8De.

** Source: www.sskj2.si/iskanje?Mode=Headword\&Query $=\%$ C4\%8De.

*** Source: Jovanović 1981: 49.

The three particle clauses (underlined) have quite similar modifying and syntactic roles: they function as modifiers reinforcing certainty, and are thus equal to particles at the level of the modifying action. This modifying role is shared by all lexical and grammatical devices which make up the particle clause. The devices which contribute to the modification value of the particle clause "če ti rečem" may be represented by the following diagram: 
če $-(\mathrm{ti})-$ reči (indicative present tense) $\rightarrow$ reinforcement of certainty

The diagram suggests that the epistemic modality is not reinforced merely by the word če but by all clause devices, grammatical as well as lexical. This reopens the issue of the word class to which če belongs. It would be misguided to classify če as a particle because, unlike such particles as morda (maybe), gotovo (certainly), tudi (likewise), že (already), it cannot have a modifying role on its own. The most appropriate label for its primary word class appears to be "conjunction", elaborated with the addition of: in a modifying role as the constituent of a particle clause.

The examples given above merit attention from a structural and syntactic perspective as well, the particle clauses being pseudo-hypotactic. At the formal level they enter into a subordinate syntactic relation, which, however, remains semantically unrealised: there is no expression of any expected conditional, temporal, concessive or other semantic relation. The clause combination "Če ti rečem, da je zanesljiv mojster" may be paraphrased as "Zagotovo je zanesljiv mojster", which proves that the particle clause is no more than a semantic modifier of the clause to which it refers, and has no structural role as a sentence element by itself.

10. Preden greš na izpit, glej, da vse še enkrat ponoviš. // Before you take the exam, see that you revise everything once more.

11. Nihče v tem filmu ne pije, kadi ali preklinja, kaj šele, da bi užival kake substance ali pa mislil na seks! $!^{8} / /$ No-one in this film drinks, smokes or swears, let alone indulges in [illicit] substances or thinks about sex!

The examples (10) and (11) differ from the preceding three. If each clause underlined in sentences (7) to (9) can function as a modifier only as a whole (that is, with all lexical and grammatical sentence-building devices jointly fulfilling the role of modification) and is thus a genuine particle clause, the modifying role in sentences (10) and (11) is not fulfilled by the clause as a whole but merely by some of its lexical and grammatical devices.

In the underlined clause of sentence (11), modification is expressed only by the particle phrase $k a j$ šele, the subordinator $d a$, and the subordinate clause structure which contains the conditional verbal mood. This observation may be demonstrated in the following diagram:

(particle) kaj šele - (subordinator) da - (hypotaxis) clause structure $-\mathrm{VF}^{*}($ conditional) $\rightarrow$ reinforcement of denial

* VF: verbum finitum.

${ }^{8}$ Source: Mladina 3, 18. 1. 2013. 
Sentence (11) thus contains no particle clause proper because, as demonstrated above, the role of modification is fulfilled merely by select lexical and grammatical devices. Nevertheless, all the examples quoted above are similar in that they all display a pseudo-hypotactic relation. In (11) this relation can be proved by a paraphrase: a tentative identification with the conjunction niti-niti (neither-nor). At the level of semantic modification, the sequence "nihče v tem filmu ne pije, kadi ali preklinja, kaj šele, da bi užival kake substance ali pa mislil na seks" might be tentatively paraphrased as: "nihče v tem filmu ne pije, kadi ali preklinja, niti ne uživa kake substance ali pa misli na seks // nihče v tem filmu ne pije, kadi ali preklinja, kaj šele uživa kake substance ali pa misli na seks." I say "tentatively" because the phrase kaj šele $(d a)$, in comparison with niti - niti, surpasses the modifying role of expressing strong denial or rejection which is attributed to it in the dictionary; in other words, it enhances the modification value of the denial. In addition to the modification value, the transformation/paraphrase itself indicates that the structure is only superficially subordinate, pseudo-hypotactic, at the syntactic level. What prevails is the meaning of intensification, which does not support subordination. We may conclude that the syntactic relation established is a coordinate one because all the clauses in the (11) sentence are syntactically equal: no-one drinks, smokes or swears, (no-one) takes drugs or thinks about sex.

To conclude, we shall briefly focus on sentence (10). The modifying role in the underlined clause is jointly fulfilled by both lexical and grammatical devices: the particle glej, the subordinator $d a$, and the indicative mood. Their modification value (reinforcement of the assertion or expression of an urgent need to perform the action) may be illustrated by still other modal devices, such as the verb morati and the particle nujno/obvezno.

(particle) glej - (subordinator) da - (hypotaxis) clause structure - VF* (indicative present or future tense) $\rightarrow$ morati (indicative present or future tense) - (particle) nujno/obvezno

*VF: verbum finitum.

The clause in question is pseudo-hypotactic as well because it is actually superordinate to the preceding clause: "Preden greš na izpit, moraš vse še enkrat ponoviti (Before you take the exam, you have to revise everything once more) // glej, da vse še enkrat ponoviš."

\section{Conclusion}

A proper conclusion is beyond the scope of this paper, as it would require a complete picture - an exhaustive corpus analysis of all possible particle clauses; moreover, it should at least hint at a possible word-class (that is, lexicographic) definition of the lexemes which assist in forming particle clauses. 
By way of conclusion, then, the paper calls for a construction-approach based survey of all possible grammatical and lexical devices which are involved in building the referential, modifying, and predicational actions. Such a survey would expand the range of possible approaches to diverse grammatical categories, including word-class definitions and syntactic relations.

\section{Bibliography}

Anton Bajec, Rudolf Kolarič, Mirko Rupel. 1956. Slovenska slovnica. Ljubljana: DZS.

Anton Breznik. 1934. Slovenska slovnica za srednje šole. Celje: Družba sv. Mohorja.

William Croft. 2009. Radical Construction Grammar: Syntactic Theory in Typological Perspective. Oxford: Oxford University Press.

Jožica Gelb. 1969. Podredje v vlogi priredja. JiS 5/14. 136-139.

Adele E. Goldberg. 1995. A Construction Grammar Approach to Argument Structure. Chicago: The University of Chicago Press.

Maciej Grochowski. 1986. Polskie partykuty. Składnia, semantyka, leksykografia. Warszawa: PAN.

Dušan Jovanović. 1981. Osvoboditev Skopja in druge gledališke igre. Ljubljana: MK.

René Métrich, Eugene Faucher, Gilbert Courdier. 1993. Les Invariables difficiles. Dictionnaire allemand-français des particules, connecteurs, interjections et autres mots de la communications. Nancy: Université de Nancy.

Mladina, 18 January 2013, no. 3.

Jacques Moeschler, Anne Reboul. 1994. Dictionnaire encyclopédique de pragmatique. Paris: Seuil.

Breda Pogorelec. 1963. Veznik v slovenščini. Doctoral dissertation at the Department of Slavistics, Faculty of Arts, University of Ljubljana.

SSKJ: www.fran.si/130/sskj-slovar-slovenskega-knjiznega-jezika

SSKJ $^{2}$ : www.fran.si/133/sskj2-slovar-slovenskega-knjiznega-jezika-2, www.ssskj2.si

Anton Sovre. 1965. "Nepravi relativniki." Jezikovni pogovori. Ljubljana: Cankarjeva založba. 125-131.

Jože Toporišič. 1974/75. Esej o slovenskih besednih vrstah. JiS 20. 295-305.

Jože Toporišič. 1991. Členki in njihovi stavčni ustrezniki. $27^{\text {th }}$ Seminar of the Slovene Language, Literature and Culture (SSJLK). Ljubljana: Department of Slavistics, Faculty of Arts, University of Ljubljana. 3-16.

Jože Toporišič. 2000. Slovenska slovnica. Maribor: Obzorja.

Branislava Vičar. 2011. Parenteza v novinarskem in parlamentarnem diskurzu. Maribor: Mednarodna založba Oddelka za slovanske jezike in književnosti, Faculty of Arts, University of Maribor.

Andreja Žele. 2014. Slovar slovenskih členkov. Ljubljana: Založba ZRC, ZRC SAZU.

Prispelo marca 2015, sprejeto junija 2015

Received March 2015, accepted June 2015 


\section{Členkovni stavki}

Členkovni stavki so jezikovna sredstva, ki opravljajo enako vlogo kot členki, le da imajo obliko stavkov. K razumevanju njihove pomenske in skladenjske vloge je nujno pristopiti s konstrukcijskega zornega kota. Konstrukcijska metoda namreč v svojo analizo hkratno vključuje tako pomen kot obliko oz. strukturo. Stavka »Če se na glavo postaviš, ti ne dam《 $\left(\mathrm{SSKJ}^{2}\right)$ na formalni ravni vstopata v podredno skladenjsko razmerje, ki pa na pomenski ravni ostaja neizpolnjeno. Gre za tako imenovano psevdohipotakso. Konstrukcijska metoda ob upoštevanju oblike in vsebine pokaže, da struktura oz. stavek »če se na glavo postaviš« kot celota opravlja modifikacijsko vlogo krepitve gotovostne naklonskoti in je kot taka funkcijsko sorodna besedni vrsti členkov oz., natančneje, modalni skupini členkov. Konstrukcijska metoda tudi pokaže, da pri krepitvi gotovostne naklonskosti ne sodeluje le raba leksema če (kot je npr. lahko razbrati iz slovarske razlage), pač pa vsak element, tako leksikalni kot slovnični, ki je del obravnavane stavčne strukture.

\section{Particle Clauses}

The role of modification is often fulfilled by particle clauses, which enter into coordinate or subordinate relations with the preceding or following clause structures only at the formal, syntactic level, leaving the semantic level relation unrealised.

An indispensable prerequisite for obtaining a grasp of the syntactic and semantic roles of particle clauses is to approach them from the construction perspective, as the construction method involves in its analysis both meaning and form, that is, structure. At the formal level, the two clauses of "Če se na glavo postaviš, ti ne dam" (SSKJ2) enter into a subordinate syntactic relationship, which, however, remains unfulfilled at the semantic level: a case of the so-called pseudo-hypotaxis. The construction method, taking into account both form and content, shows that the clause "če se na glavo postaviš" as a whole reinforces the certainty (epistemic modality), and is thus functionally akin to the word class represented by particles or, more precisely, to the modal group of particles. Moreover, the construction method shows that the reinforcement of certainty is due not only to the use of the lexeme če (as the dictionary explanation seems to suggest) but to every element, lexical or grammatical, which forms part of the structure in question. 